\title{
Interdisciplinary integration on sustainable development issues
}

\author{
Dmitry Sergeyevich Ermakov ${ }^{1, *}$, and Alexander Sergeyevich Ermakov ${ }^{2}$ \\ ${ }^{1}$ Peoples' Friendship University of Russia (RUDN University), Department of Psychology and \\ Pedagogy, 117198, 6 Miklukho-Maklaya Street, Moscow, Russia \\ ${ }^{2}$ Lomonosov Moscow State University, Department of Embriology, 119991, 1, b. 12 Lenin Hills, \\ Moscow, Russia
}

\begin{abstract}
In order to achieve sustainable development, we need a deep understanding of both social and humanitarian processes and relationships in living and non- living nature. The development of scientific research areas that are related to sustainability are very important. Unfortunately, sustainable development is not among scientific and technical priorities in Russian Federation. This study analyzes the dynamics of $\mathrm{PhD}$ and Doctoral dissertations on sustainable development performed in various areas of science in the USSR and Russia in 1987-2019. The majority of dissertations (1 322 in total ) were in the area of economics (85.4\%), while significantly fewer were in philosophy (2.9\%), technical $(2.3 \%)$, and geographical $(2.2 \%)$ sciences. There are almost no dissertations in the fields of biological and chemical sciences, pharmaceutics and medicine. Our data indicate a significant imbalance and economic bias in the study of sustainable development issues. In this regard, it can be assumed that interdisciplinarity, which can be implemented in the framework of convergent and transdisciplinary approaches, is one of important methodological problem of sustainable development. Examples of relevant interdisciplinary projects are considered.
\end{abstract}

\section{Introduction}

In regard with the adoption of the sustainable development goals (2015) [1], the challenges of practical sustainability are even more important now than three decades ago, when they were formulated, since they go beyond purely environmental, economic and social problems and affect the survival of humanity [2]. In relation to this, it is necessary for science to meet the needs not only of the international community, countries and governments, but also of numerous other actors. In our opinion, sustainable development as an innovative strategy for the development of civilization, which takes into account the balance of three components of the environment: nature, society and economy, is one of the important fundamental problems and requires special understanding from the point of view of history, philosophy, methodology, organization, and ethics of science. The decisions of all UN conferences and summits on environment and development (Stockholm, 1972; Rio

\footnotetext{
* Corresponding author: ermakov-ds@ rudn.ru
} 
de Janeiro, 1992, 2012; Johannesburg, 2002) emphasize an importance of scientific research. The concept of the transition of the Russian Federation to sustainable development (1996) also declares the leading importance of science.

At the same time, sustainable development in our country is not among the priority areas for development of science and technology, according to the list of critical technologies of the Russian Federation. Nomenclature of scientific specialties [3] does not assume levels of candidates of science (PhD) and doctors of science (DSc) in this field.

\section{Research Methods}

Since 2011 we conduct scientometric research [4], which is based on content analysis of the catalog of the electronic library of dissertations by the Russian State Library (diss.rsl.ru). This catalog highlights dissertations for the degree of Candidate of Science (approximately equivalent to the western $\mathrm{PhD}$ ) and Doctor of Science (approximately equivalent to $\mathrm{DSc}$ ), the subject of which includes the words "sustainable development" (taking into account morphology). Dissertations are distributed by branches of science in accordance with the nomenclature of scientific specialties, according to the approval of the Ministry of Education and Science [3]. This method is well known and widely used, and, particularly, in the field of sustainable development [5]. It should be noted that the results of a similar study [6] were published without the reference to the original source.

\section{Findings}

In total, since 1987 till 2019, 1322 dissertation studies on the problem of sustainable development were completed, including $1115 \mathrm{PhD}$ and $207 \mathrm{DSC}$, in the Russian Federation (and in the Union of Soviet Socialist Republics until 1992) (Figure 1).

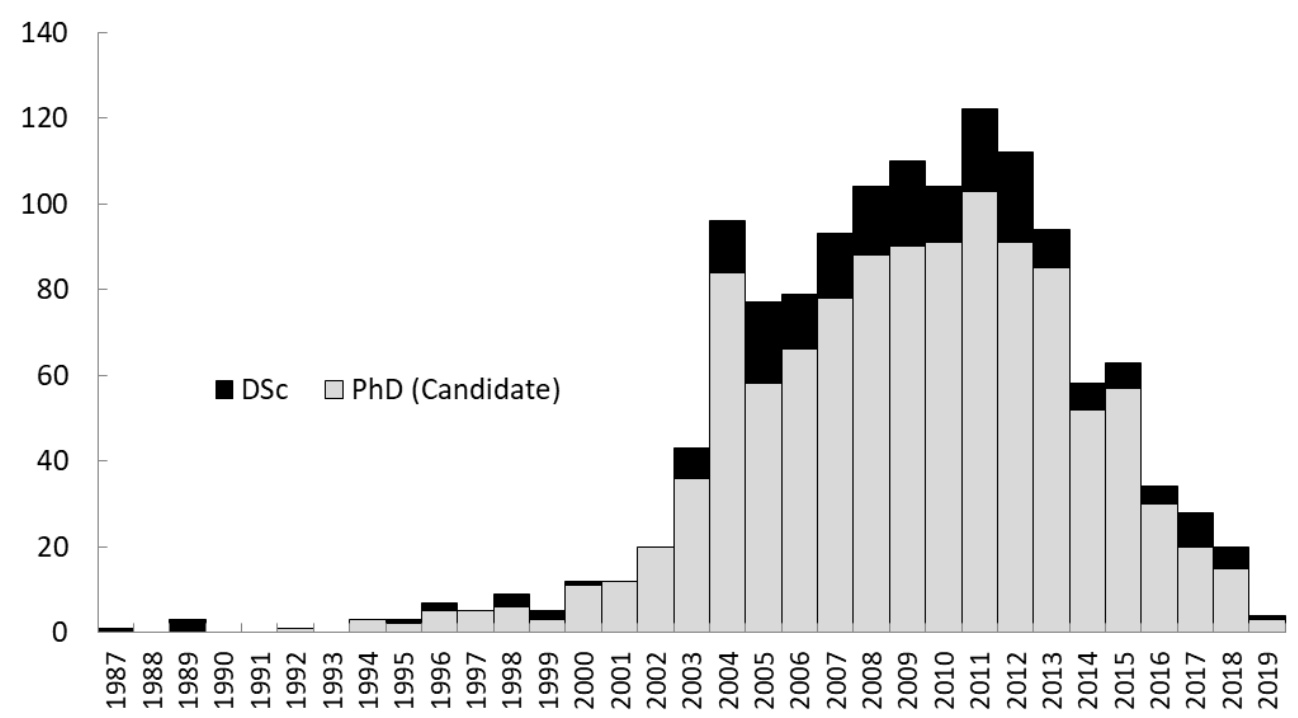

Fig. 1. Dynamics of dissertation researches on the problem of sustainable development.

The largest number of dissertations (more than 100 per year) occurred in 2009-2012. Subsequent decline after 2012 can be explained by organizational conditions (restructuring 
of the network of dissertation councils, increasing requirements for both the level of thesis themselves and the thesis councils in which they are defended [6]).

However, in our opinion, the reasons for this are of a methodological nature: first, a decrease in interest in the studied problems, and secondly, the mismatch between the disciplinary structure of traditional science and the integrative nature of sustainable development as a socio-ecological and economic phenomenon.

As we can see from Table 1, the vast majority of the works that were considered in this research, were performed in the area of economics (85.4\%), followed with a huge gap by philosophical $(2.9 \%)$, technical $(2.3 \%)$ and geographical $(2.2 \%)$ sciences. There are separate dissertations on political and pedagogical (1.3\%), sociological $(1.1 \%)$ sciences, law $(0.6 \%)$, biological and psychological $(0.5 \%)$ sciences, architecture $(0.5 \%)$. Very few studies were carried out in the field of physics and mathematics $(0.3 \%)$, cultural studies, agriculture, geology and mineralogy $(0.2 \%$ each $)$, and also $(0.1 \%$ each) in the fields of historical, pharmaceutical and philological sciences. The ideas of sustainable development are not considered at all in the aspects of veterinary medicine, theology and chemistry

Table 1. Distribution of dissertation research by branch of science.

\begin{tabular}{|l|c|l|c|}
\hline \multicolumn{1}{|c|}{ Branch of science } & $\begin{array}{l}\text { Number of } \\
\text { dissertations }\end{array}$ & \multicolumn{1}{|c|}{ Branch of science } & $\begin{array}{c}\text { Number of } \\
\text { dissertations }\end{array}$ \\
\hline agricultural science & 3 & pedagogical science & 17 \\
\hline architecture & 6 & pharmaceutical science & 1 \\
\hline biological science & 12 & philological science & 1 \\
\hline chemical science & - & philosophical science & 38 \\
\hline culturology & 2 & $\begin{array}{l}\text { physical and mathematical } \\
\text { sciences }\end{array}$ & 4 \\
\hline economics & 1129 & political science & 17 \\
\hline geographical science & 29 & psychological science & 6 \\
\hline $\begin{array}{l}\text { geological and mineralogical } \\
\text { sciences }\end{array}$ & 3 & technical science & 30 \\
\hline historical science & 1 & theology (since 2015 г.) & - \\
\hline juridical science & 8 & veterinary science & - \\
\hline medical science & - & total & 1322 \\
\hline
\end{tabular}

It is obvious that social and humanitarian aspects prevail. Understanding of sustainable development issues from the point of view of natural sciences is less common, as the scientific justification of the relevant technologies. It should be noted that the ideas of sustainable development have a long history. However, today the "concept of sustainable development" is a conglomerate of heterogeneous philosophical, environmental, sociological, economic, technological, etc. ideas that have no unity: dozens of definitions, principles, criteria, concepts, strategies, lists of indicators.

At the same time, a number of scientists criticize the formulation of the question of sustainability of development: development means change, and sustainability, on the contrary, means stability [7].

In this regard, we can assume that an important methodological problem of sustainable development is interdisciplinarity, which can be implemented within the framework of two approaches: convergent (includes blurring the boundaries between separate scientific disciplines, between scientific and technological knowledge, which opens up opportunities for creating objects in all spheres of human activity that are close in function and purpose to natural ones) [8] and transdisciplinary ( a way of considering a subject when solving complex problems of nature and society outside the framework of traditional scientific disciplines, simultaneously at several levels) [9]. Examples of practical application of these approaches are the projects implemented with the participation of the authors: "Valaam island is our common home", "Living village". To solve the problems of sustainable 
development of the Valaam archipelago on the Ladoga lake, Republic of Karelia, Russia, and its population, an interdisciplinary team of experts, including specialists in the fields of geography and ecology, economics, law, management, philosophy, psychology and conflict studies, philology and arts, sociology, pedagogy, etc., worked at that area. Taking into account the principles of system analysis, this team studied the processes of crisis and mechanisms of local community development, the conditions for overcoming the crisis and sustainable self-organization, based on social partnership, dialogue and responsible leadership, joint decision-making and collective practices like disposal of solid municipal waste, energy efficiency, development of infrastructure for culture, education and health of the population, tourism, formation of children's craft and environmental skills, strengthening of local self-government [10].

The "Living Village" project, which is implemented in the Ustyansky district of the Arkhangelsk region, provides not only interdisciplinary integration, but also work at different scales, at different levels: mental and physical, theoretical and practical, global and local. Its goal is to reproduce the traditional way of life and types of rural labor of the indigenous peoples of the North of the Russian Federation. Transformation of the rural area is one of the key priorities of sustainable development. At the same time, it is important to teach the villagers to live in their natural and cultural environment, not just preserving it, but conducting economic activities in a symbiotic landscape! In this regard, a promising innovation (paradoxically) is the revival of the traditional way of life, which provided the person and the community with the necessary products in conditions of limited and hard-toreach natural resources, based on the principles of self-organization, intentionality, common thinking, ideas, values, etc.

The project defines the conditions for sustainable rural development, based on the annual economic cycle of the northern village, including harmonious interpersonal relationships, the relationship of generations, the participation of elders in the education of young, self-government, revival of traditional types and modern types of labor and employment, participation of residents in settlement development, full use of available renewable resources, conservation of natural and cultural heritage [11, 12].

\section{Conclusion}

Despite the popularity of sustainable development, there is a risk of turning "sustainable development" into a fashionable rhetorical cliché. The term is used to describe a goal that is certainly desirable, but is defined so broadly, from fairly accurate to very vague interpretations, that it can lead to misunderstandings [13]. It is obvious that sustainable development is an iterative process which involves many disciplines and points of view, requiring linking the production of new scientific knowledge with practical solutions to specific problems, including the creation of technological innovations [14].

Since the beginning of the discussion initiated by the publication of the report "Our common future" (1987), many attempts have been made to define the science of sustainability [15]. However, based on the actual results, it is doubtful that we have made progress: many problems (climate change, biodiversity loss, poverty and discrimination, etc.) remain unresolved, or their scale and consequences are even increased. Sustainable development issues are complex and should be integrated into both traditional disciplines and integrative trans-disciplinary research programs, the results of which would contribute to the improvement of the environment, society and human condition [16].

The reported study was funded by Russian Foundation for Basic Research according to the research project № 19-013-00722 “Education for sustainable development in action”. 


\section{References}

1. Transforming our world: the 2030 Agenda for sustainable development. URL: http://www.un.org/ga/search/view_doc.asp?symbol= A/RES/70/ 1\&Lang=E (2015)

2. E. Kumi, A. A. Arhin, T. Yeboah, Env. Dev. Sust., 16, 539-554 (2014)

3. Nomenclature of scientific specialties. URL: http://docs.cntd.ru/document/542610966 (2017).

4. Scientific and methodological support of environmental education for sustainable development. URL: http://disus.ru/konferencii/364554-1-nauchniy-otchet-grantuprezidenta-rossiyskoy-federacii-dlya-gosudarstvennoy-podderzhki-molodih-rossiyskihuchenih-doktorov.php (2011).

5. Sustainability science in a global landscape (Amsterdam, Elsevier, 2015)

6. D. V. Vlasov, Vestn. Mosk. Univ. Geogr., 1, 16-23 (2017)

7. A. S. Ermakov, D. S. Ermakov, Chem. Life, 11, 24-29 (2012)

8. Converging technologies for improving human performance. Nanotechnology, biotechnology, information technology and cognitive science (Dordrecht, Netherlands, Kluwer Academic Publishers, 2003)

9. D. J. Lang, A. Wiek, M. Bergmann, M. Stauffacher, P. Martens, P. Moll, M. Swilling, C. J. Thomas, Sust. Sci., 7, 25-43 (2012)

10. D. Yermakov, D. Slavinsky, S. Chernikova, Environmental ethics: the power of ethics for sustainable development (Vilnius, M. Romeris University, 2010)

11. A. Kulyasova, Vestnik Commis. Rus. Fed. UNESCO (2015)

12. A. A. Kulyasova, A. S. Ermakov, D. S. Ermakov, Psychology of extreme professions (Northern (Arctic) Federal University, Arkhangelsk, 2019)

13. J. A. Dixon, L. A. Fallon, Soc. Nat. Res., 2, $73-84$ (1989)

14. G. Wuelser, C. Pohl, Sust. Sci., 11, 789-800 (2016)

15. T. R. Miller, Sust. Sci., 8, 279-293 (2013)

16. R. J. Baumgartner, J. Korhonen, Sust. Dev., 18-2, 71-75 (2010) 